\title{
THE LAST LABORATORY
}

\author{
Raise a glass to chemistry.
}

\section{BY JOHN GILBEY}

$\mathrm{F}$ rom the window of our coffee room you get an excellent view of the Gothic, vaguely sinister, Registry building. My colleagues and I, the hardcore survivors of the New Year lunch party, watched with a sense of numbed expectation as two porters dismantled the Christmas tree in the dank, grey twilight. January is not the right time for bad news.

The flag hanging limply above the door showed that the Senate was in session, and, although the agenda used language like 'Management of Academic Risk Resulting From Tactical Resource-Balancing', it was clear what the real decision was expected to be. After 100 years of solid, if unspectacular, teaching and research, the University of Rural England intended to close its chemistry department.

Our professor strode from the gaunt limestone portal, paused, then threw his meeting papers to the ground. The porters looked on in bemusement as he began, slowly at first and then with uncontrolled fury, to jump up and down on the documents - mashing them to pulp in the melting snow. As our phones pinged with the expected incoming e-mail, we turned dejectedly from the window and raised our glasses in a solemn toast to the department. The party broke up in dissolute disillusion, but as I put on my coat, I realized that one important person would still be ignorant of the news, so I went to find Jim - our glassblower, tea-brewer and father-confessor.

I stopped in the open doorway and tapped gently on the frame. "With you in a minute, John ..." came a slightly muffled voice from behind a stereo microscope. As the gas jet roared, I looked around the cluttered space that was Jim's workshop. Old bits of glassware, tagged like the occupants of a morgue, stood in heaps; colourful family photos - tokens of thanks from former students covered one noticeboard; and grey industrial ovens throbbed in the shadows.

The elderly man sat back from the dark teak bench, stretched mightily and turned to look at me. "They've decided then," he stated, waving me towards an old horsehair sofa half covered in junk. I nodded and settled into it — shoving aside a pile of old journals.

"How did you know? You don't use e-mail, do you?"
Jim laughed and pushed his safety glasses farther up his nose. "Nah, I don't hold with computers - they make life too complicated. Sid the porter was just in, told me about the prof's little dance routine over the road - he reckoned he might show some promise if he ever took up the tango."

I tried to picture this development - but failed.

"Anyway," said Jim. "What are they going to do? You can't just stop teaching chemistry..."

I explained the plan to form an integrated science department, building on what physics and computer science had already

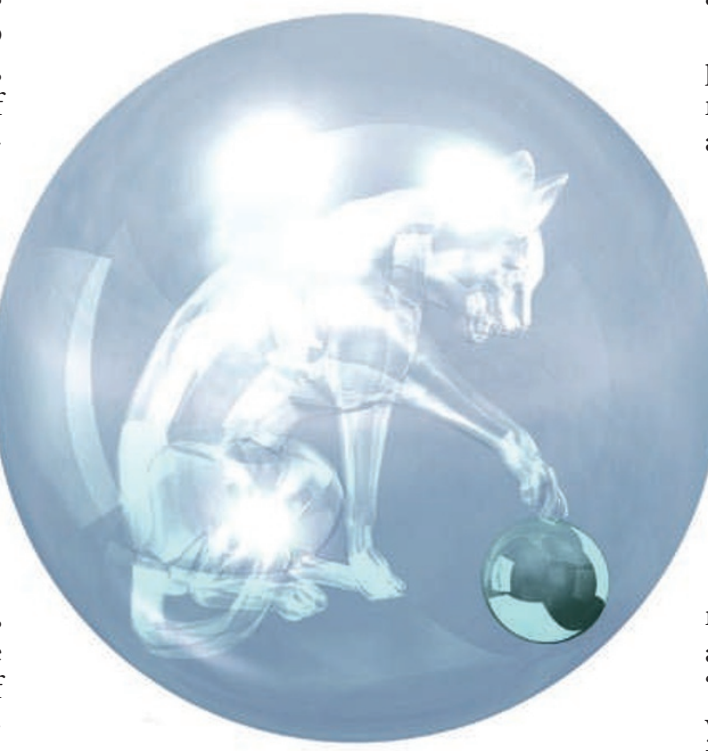

attempted. He shook his head as I told him about the closure of the labs themselves with all practical study being replaced by simulations, and the generation of materials being restricted to the new, robot-driven Synthetics Fabrication Centre on the edge of the campus.

Jim scratched his bald head. “Doesn't seem right to me somehow," he said. "People need to see, touch and smell the stuff they're working with." I pointed out that the new VR system did exactly that, but Jim waved the concept away. "It just ain't the same look ..." He reached across and handed me a glass ball about a centimetre across. It felt cool and light, with an exquisite silky texture
DNATURE.COM Follow Futures on Facebook at: go.nature.com/mtoodm
2011: YEAR OF CHEMISTRY Celebrating the central science nature.com/chemistry2011
- and when I gazed into it I could see a tiny glass figure, a tabby kitten frozen in the act of dabbing at a coloured ball. It was utterly perfect.

“That's amazing — how did you do it?"

The glass-blower allowed himself a slow smile. “That would be telling ... It's for young Mercedes - she's got her viva next week, and I reckon she'll sail through. Here, take a closer look." He handed me an unmounted glass lens and I held it in front of the ball.

"Have you got anything with a bit more magnification?" I asked. “This doesn't really help much."

Jim leaned across conspiratorially, "Give it a squeeze ..." he said with a grin.

I did, and nearly dropped it. As I applied pressure to the cold glass lens, it deformed in my grip - remaining circular but shrinking and becoming thicker.

The lens now made the kitten look close to life size - and it still looked perfect. I tried a couple of questions, but couldn't get beyond "How ...?"

Jim eased both lens and ball from my fingers and placed them carefully back on the bench, then perched on the arm of the sofa. "I was apprenticed to $\mathrm{Mr}$ Chambers - my predecessor - for seven years, back in the day. He had some big ideas about the chemistry of glass - it was him got me into using botanicals." Jim nodded to a shelf full of dark bottles I'd long assumed to contain home-brewed wine. "Folk have been doing that for thousands of years - adding wood ash and such to glass. I just happened on some especially useful tinctures. That's what chemists are supposed to do, isn't it?"

"But Jim, this changes everything!" I whooped. "They can't close us down now!" A sudden thought struck me. "Will the lenses be easy to manufacture?"

Jim looked suddenly glum. "Ah, there's the thing. It's really tricky - all to do with balancing internal stresses. The secret's in the annealing. It's certainly nothing those fancy 3-D printers could handle. I'll have to train folk up to do it."

In my mind, I tried to picture what sort of dance the professor would attempt this time.

John Gilbey is visionary-in-residence at the University of Rural England. He is proud to have been taught by many intriguing technical staff - all of whom had a few tricks up their sleeves. 